\title{
Khat: Is It More Like Coffee or Cocaine? Criminalizing a Commodity, Targeting a Community
}

\author{
Ezekiel Gebissa \\ Kettering University, Flint, USA \\ Email: egebissa@kettering.edu \\ Received January $4^{\text {th }}$, 2012; revised February $5^{\text {th }}, 2012$; accepted March $4^{\text {th }}, 2012$
}

\begin{abstract}
This article looks at the expansion of khat chewing from the Horn of Africa to Western countries. It assesses the reaction of various sections of US society toward a practice they perceived as a dangerous new "drug" and a possible source of funding for terrorist groups by documenting the effect on Oromo immigrants of a nationwide crackdown by law enforcement. For the new immigrants, chewing khat provides a setting that connects them to the homeland and eases the vicissitudes of integration into the host culture, but the practice is illegal. It also shows how the media and political interest groups have shaped public perception of chewing khat in a negative light and precipitated the promulgation of hasty policies that have made Oromo immigrants targets of law enforcement. The article urges users to exercise discretion in a political environment that is not ready to restore fairness and rationality to policymaking.
\end{abstract}

Keywords: Cathinone; Drugs; Terrorism; Immigration; Traditional Use; Law Enforcement

\section{Introduction}

In the last two decades, $\mathrm{khat}^{1}$ has migrated from the traditional use regions in the Horn of Africa and the Middle East to Western countries. Unlike other psychotropic plants such as coffee or tea that arrived in the West as commodities, khat was brought by immigrants from the Horn of Africa, including many Oromo from eastern Ethiopia, who are active users of the leaves (Carrier, 2007b; Gebissa, 2010b: p. 609). The introduction of this new substance has created moral indignation and political consternation in some countries not just over the potential social harm of what is presumed to be a new "drug" but also about the impact of immigration on the host societies (Manghi et al., 2009: p. 4). In the United States, the reaction to khat has evolved over time from its being viewed as a "strange" immigrant habit that posed little harm to the host communities, to its being deemed a "harmful" drug that should be fought as part of the "war on drugs," finally to being treated as an illicit commodity financing terrorism (Carrier, 2007a: pp. 242-245; Kushner, 2004: pp. 86-94). Swept up in the undiscriminating dragnet of law enforcement, many Oromo immigrants have been arrested, convicted, and sentenced to time in prison for their use of khat (Crenshaw \& Burk, 2004: p. 12).

In this paper, I present three settings in which khat plays a role to illustrate varied perceptions of khat chewing in each case and show how a traditional cultural practice that offered a tangible link to the homeland for many Oromos in the diaspora has caused difficulties of integration into their new sociocultural environment. I begin with khat chewing in the traditional setting, shift to the new setting in the West, illustrating the reaction of law enforcement in the United States, and conclude by

${ }^{1}$ Khat is a psychoactive substance that has been chewed in the Horn of Africa and the Arabian Peninsula for nearly a millennium. The title is adopted from Cynthia Dizikes, "Khat-is it more coffee or cocaine? The narcotic leaf is a time-honored tradition in Africa but illegal in the US where demand is growing, Los Angeles Times, 3 January 2009. highlighting the confusing terrain of scientific knowledge about khat that gives rise to unfounded popular claims.

\section{In the Traditional Setting}

As we know it today, khat chewing started among the urban residents of the ancient walled city of Harer in eastern Ethiopia, whence the practice spread to the surrounding Oromo. For the Muslim Oromo of rural Harerge, khat is valued for its critical role in such productive activities as work, meditative worship and cultural ceremonies. Farmers chew it for energy in their labor-intensive daily activities and religious devotees for all night sessions of prayer during Ramadan. Khat is also chewed on such important events as births, marriages, funerals, and naming ceremonies. During the festivities of the popular wadaja ritual-a ceremony of group prayer performed at times of illness, death, or calamity-large amounts of khat are consumed by the participants. As such, khat chewing plays an integral role in Oromo cultural institutions that facilitate social interaction and cultural integration (Gebissa, 2004: pp. 9-10; 2010a: pp. 75-77; Ahmed, 2010: pp. 16-20).

Among the urban Oromo in many cities and towns in Ethiopia, khat is used for recreation, for social pleasure, and as a medium of social interaction. The barcha, the afternoon chew, is a popular and commonplace sight in urban centers, where friends, relatives and acquaintances congregate in a designated room equipped with chew accessories. Participants lie on their sides against a pile of cushions to meditate, read and engage in the talk of the town while chewing khat leaves. Unlike the rural chew custom, the urban barcha session is often followed by consumption of alcoholic beverages called chabsii, literally "to break [the high]," i.e., to counteract the inebriating effects of khat and allow for sound sleep (Gebissa, 2004: p. 9; Mains, 2010: p. 38).

Regardless of where and when they take place, the chew sessions provide the social context in which peaceful and con- 
structive interaction occurs. Khat chewing provides individuals a comfortable atmosphere for conversation and strengthens social cohesion. It serves as the preferred social lubricant for fostering comity, cooperation, and conviviality. As a social institution, the chew session is used to seal important and longterm contracts such as marriage and enliven the worship practices of the Muslim population of Harerge (Gebissa, 2010a: p. 75). Emphasizing the critical cultural role and meaning of khat in Harerge, one historian summed up the rationale for khat chewing as: "the Oromo, the Adere, the Afar and Somali counted [khat] among the essentials necessary for living, work, and enjoyment. Guests are welcomed with it; prayers were kept long and lively with it; in wedding and funeral ceremonies as well as other social gatherings people were supplied with bunches of the leaves as a matter of courtesy" (Tafla, 1982: p. 292). In these societies, khat chew sessions continue to have vital social and cultural functions that create strong bonds among the participants. Despite serving as such an important social institution in its traditional setting, khat chewing can engender fear in outsiders.

Oromos began settling outside their homeland as early as the sixteenth century, but sizeable diaspora communities began to emerge only recently. By 1974, according to Mekuria Bulcha (2002), the number of Oromo refugees in the countries adjacent to Ethiopia had reached an estimated 60,000. During the period of the military (derg) rule (1974-1991), drought, famine, civil wars, and political persecution drove many more Oromos to refugee camps in Sudan, Djibouti, Somalia, and Kenya. In the 1980s, the number of Oromos departing the eastern provinces of Ethiopia grew steadily as a result of the forced villagization and resettlement schemes of the derg regime, the Ethio-Somali War, and successive campaigns against Oromo insurgents (Bulcha, 2002: pp. 53-60, 165-173). The exodus continued in the 1990s as human rights violations increased and Oromos settled in refugee camps in the neighboring countries. The majority of them happened to be from the khat production and consumption regions Harerge and Bale. These refugees were eventually resettled in Western countries, with considerably large numbers the United States. The nature of their resettlement allowed the refugees to have their families join them in the West (Kumsa, 2005: p. 180). Oromo communities gradually developed in Minneapolis, Washington, Portland, Columbus, Atlanta, Nashville and several cities in the Great Plains (Getahun, 2006: pp. 128131).

In their new milieus, the immigrants endeavored to recreate the homeland in ways that allowed them to cope with the depredations of adjustment. For those Oromos who came from Ethiopia's eastern provinces, khat chew sessions provided a familiar setting for seeking connectedness, conversation, and cooperation. The act of chewing fresh khat in a group, surrounded by friends, provided an atmosphere of social harmony imbued with generosity, pleasure, friendship, and tranquility. It also offered a chance for connecting to a familiar taste, a comfortable atmosphere for counseling on integration into the new location, and a setting for social interaction, enlivened by reminiscences as well as news from home (Hart, 1997; Blount, 1996: p. 279; Stevenson et al., 1996: p. 80). By the 1990s, regular air travel to East Africa had made relatively fresh khat available to the budding immigrant communities in the US (Manghi et al., 2009: p. 4). What the immigrants deployed as a cultural institution that actively promoted social integration, a custom as common as having a cup of coffee, nevertheless set them on trajectory that clashed with the values, drug laws, and norms of their new setting (Grayson, 2008: p. 117).

\section{The View from the Road}

When khat began to be noticed in the US in the early 1990s, the reaction was one of disdain and indifference. Media reports depicted khat chewing as a strange habit of some Middle Eastern immigrants whereby people spent a large portion of their incomes and about a third of their day chewing leaves called khat (Kwiatkowiski, 1993). The American public was unfamiliar with the practice and opinion makers showed little or no concern about it (Crenshaw \& Burk, 2004: p. 12). John Lancaster, a reporter of The Washington Post tried some khat and concluded its effect was too mild to have crossover appeal to Western users. He described his experience of chewing as follows:

It was an hour into my first khat chew, and so far the experience had been something of a letdown. I was not euphoric, or even mildly lightheaded. God was nowhere in sight. The dominant sensation, in fact, was of sore gums and a painfully distended cheek. ... four hours of masticating what looked like hedge clippings seemed a high price to pay. From now on, I'm sticking to beer (Lancaster, 1997: p. B01).

Apparently authorities viewed khat as generally harmless for the same reasons. The official position of the DEA was that American users would opt for more potent street drugs than chewing leaves. Asked about a new "drug” used by young men in the Minneapolis, a DEA official said: “we don't really think that Americans would spend hours chewing leaves to get a mild rush of euphoria when they could get instant effect from one gram of amphetamine" (The Drug Connection, 1989). The agency maintained for a long time that, despite reports of use by some Caucasians, khat "likely will not become widely popular [in the US] due to its limited shelf life and because stimulant abusers commonly seek more intense physiological effects, such as those produced by cocaine and methamphetamine" (DEA, 2003). At the time, it all made sense. ${ }^{2}$ The apparent lack of concern of journalists and authorities was shared by the most xenophobic group called "Friends of the US Border Patrol," which otherwise would have been vocal decrying the smuggling of khat into the United States. From the group's perspective, "the narcotic is an acquired taste and certainly not for an American palate” (quoted in Carrier, 2007a: p. 244). Official consensus was apparently that khat was not potent enough for the least experienced Western user and unlikely to spread to the general population.

The indifference was nevertheless short-lived. Somalia's descent into chaos in the early 1990s and the consequent human suffering brought the Western media to the doorsteps of the khat culture. In an effort to underscore the horrendous condition of life in stateless Somalia, reporters depicted khat in rather ominous terms. In May 1992, the US News and World Report reported:

Heavily armed fighters wander through Mogadishu's desolate streets, striking elaborate Rambo or Chuck Norris poses and firing their Kalashnikovs or G-3 rifles from behind shattered walls and doorways. One or two blocks away, their opponents do exactly the same thing. Most of these warriors have been chewing khat... a leaf containing a mild amphetamine that

${ }^{2}$ Even in 2000, Stan Skowronski, DEA spokesman in New York was nonchalant stating clearly that khat "is probably not one of our priorities" (Hays, 2000). 
is smuggled in daily by plane from Kenya (Giradet, 1992: pp. 38-41).

Reporting from Baidowa an American journalist wrote in September 1992 describing a scene in refugee camps: “And through that eerie scene saunter boys and young men, dazed by an amphetamine-like drug called khat, shouldering weapons with which they wage battles for control of stolen food and aid supplies” (Wallace, 1992: p. 21). The Economist (1992: p. 41) chimed in depicting Somalia as a wasteland "ruled by roving gunman in their aviator sunglasses, high on the intoxication of weed khat." According to Jonathan Stevenson, khat was the cause for everything that was wrong in Mogadishu in 1992. He wrote in the New Republic:

After taking the drug, restless adolescents become more and more agitated and less and less rational. A drug-conjured insistence on personal supremacy turns pubescent energy into casual, cheap violence. Raw tempers are released in the form of reckless driving, senseless arguments, and the playful exchange of gunfire. Gunshot wounds in Mogadishu. ...peak in the early evening hours, when the young gunmen are at the apex of their khat sprees. "You find easy solutions to all your problems on khat," says Mohamed Abshir"... "The problem is that Somalis' problems are other Somalis” (Stevenson, 1992: p. 18).

In early December 1992, the United States deployed its troops in Mogadishu. There were surprises for American troops. According to the US New and World Report, the Pentagon was unprepared for the "khat factor" and did not know how "to determine what US soldiers ought to do when confronted with an armed man who has just consumed the equivalent of six cups of espresso" (US News \& World Report 1992). The then US Assistant Secretary of State for Africa reinforced the confusion by attributing the violence in Somalia to "teenage khatchewing Rambos getting pumped up for early evening raids" (quoted in Carrier 2007b: p. 196). It was no longer a tenable position for law enforcement in the US to maintain an indifferent attitude towards khat.

The primary concern of authorities in the early 1990s was the fear that khat might be another dangerous street drug. Before khat chewers arrived in American cities in significant numbers, public opinion had already been shaped by the media to regard khat chewing as wasteful, hedonistic, and dangerous, and its chewer as a violent maniac who would stop at nothing to get his way. As more and more immigrants from the Horn of Africa arrived in the US, Americans' legendary anxiety over drug abuse was compounded by their perennial apprehension over the impact of immigration.

The Battle of Mogadishu of October 3-4, 1993 in which 18 American servicemen were killed was a key event in crystallizing the negative public opinion about khat and its chewers in the US. Americans were shocked by images of Somalis fearlessly charging at the heavily-armed American troops and triumphantly dragging the bodies of dead American soldiers in the streets of Mogadishu. Their apparent inhumanity was readily blamed on the khat the Somali men chewed. At the same time some Pentagon officials speculated the poor performance of American soldiers was due to their predilection to experiment with an exotic drug called khat (Mitchell, 2001).

The debacle not only imprinted a very negative image of khat in the popular imagination but also forced officials of the Drug Enforcement Agency (DEA), who only a few years prior were dismissing khat as unappealing to Western users, suddenly to revise their official stance on khat. On January 14, 1993, the DEA issued a "final rule" declaring khat "an illegal plant" on the basis that khat contained cathinone. The Food and Drug Administration (FDA) also revised its existing advisory to law enforcement officials to detain any khat plant coming into the country (Anderson \& Carrier, 2006: p. 150; Beckerleg, 2008).

The American public was given another dose of reality that khat was a dangerous drug with the release of the movie Black Hawk Down. In the book by the same title, author Mark Bowden wrote:

"Many Somali men, particularly the young men who cruised around Mogadishu on "technicals," vehicles with 50-culber machine guns bolted in the back, were addicted to khat, a mild amphetamine that looks like watercress. Mid afternoon was the height of the daily cycle. Most started chewing at about noon, and by late afternoon were wired, jumpy, and raring to go" (Bowden, 1999: p. 21).

Scenes from the movie presented Somalis as intoxicated by khat and ready to kill. The alleged link between khat and violence was further reinforced by a self styled anti-illegal immigration group, "Friends of the US Border Patrol," which appeared on the internet in 2004. According to Neil Carrier (2007a: p. 244), this group not only presented khat chewers as obsessed with violence, with its website featuring a picture of a supposedly khat-crazed Somali militiamen waiting for a wayfarer to kill, but also explicitly linked khat with illegal immigration. Referring to Somalia, the piece declares that "the number of violent and illegal aliens in America at this moment from that part of the world can be calculated by the amount of this drug being smuggled into the country (Carrier, 2007a: p. 244).

It is important to note that the DEA's opinions do not have the force of law and the FDA's advisory relates to the detaining of the substance, not the possessor. Regardless, several states rushed to pass laws that made the possession of khat illegal without bothering to acknowledge the khat-cathinone distinction evident in the federal regulatory rules. In the subsequent years, many Oromos were arrested for possession of khat and their cases were brought to trial in many states. Hundreds of cases resulted in convictions under state laws and many Oromos were sentenced to prison terms. ${ }^{3}$

When the cases made their way through to the federal courts, three US Circuit Courts ruled that the khat plant, as opposed to the cathinone that may be found in it, "[was] not a controlled substance" because "neither the U.S. Code nor the Code of Federal Regulations" lists it as such. Some of the chemicals that are sometimes found in-but not always found in it- are illegal” (Armstrong, 2008: p. 637). The difference is, according to Sidney L. Moore, a defense attorney specializing in khat cases, one needs "to chew about $650 \mathrm{lb}$ of khat to squeeze $1 \mathrm{gm}$ of cathinone out of it” (Gardiner, 2006). That is an impossible task even for the orally dexterous chewer. As a legal matter, therefore, khat itself was not deemed illegal under the jurisdictions of the courts of appeal that have ruled for the defendants (Sixth Circuit, 2005; Fourth Circuit, 2005; Second Circuit, 2008).

So what was fueling the determination of US authorities to continue to prosecute khat chewers? There has never been a clear-cut case where khat was directly linked to violence ${ }^{4}$ as a

\footnotetext{
${ }^{3}$ Local newspapers report that Oromos were arrested and convicted in several states: California, Georgia, Massachusetts, Michigan, Minnesota, Missouri, Nebraska, New York, Ohio, Pennsylvania, South Dakota, Tennessee, Texas, Virginia, Washington, Wisconsin, and Washington DC.
} 
causal agent or any evidence of misuse of khat by the general public in the West (ACMD 2005: pp. 16-19, p. 28). The concern of law enforcement has been that a stronger and more portable form of khat could spread from the large immigrant communities to the host communities (Stancliff, 2009). In this regard, they were apparently spooked by a pill known as hagigat (more or less Hebrew for "party khat") that showed up in 2003 in kiosks in Israel (Urquhart, 2005; Crenshaw \& Burk, 2004: p. 13; Bentur et al., 2008: pp. 206-210). American authorities viewed the fact that a khat derivative quickly spread from the Yemeni Jewish groups, where khat chewing had remained confined since the 1950s, to the larger Israeli society to underscore the possibility that anyone can refine plant essences relatively easily (Litman et al., 1986). However, as writer Dave Stancliff (2009) put it, "the effects of this particular party pill would make our country's meth heads laugh. Its potency doesn't compare with the cocaine, methamphetamine, and other nasty drugs on the list.” The assurance of a journalist, however, was not going to make law enforcement stand down from intensifying what it believed to be a new frontier in the "War on Drugs."

So is khat more like coffee or cocaine? Opinions vary. Many experts challenge the assertion that khat represents a new drug of abuse in the United States. Scott Lukas, director of the behavioral and psychopharmacology lab and associate professor of psychiatry at Harvard University Medical School, is categorical and definitive that the adverse effects of khat are exaggerated. He says:

[khat] has such a low potency that a suitcase full would probably be enough for one person... because the active ingredients are absorbed rather slowly you do not get huge amounts of it into the body at once. The way the drug is delivered makes it very hard for abuse to develop... but the ephedrine-like effects in khat are closer to Marlboro cigarette than a cup of java. It's more like a nicotine patch (Mitchell, 2001).

The scientific consensus is that the effects of khat use cannot technically be described as addictive and khat is not categorized as an addiction-producing drug but rather a kind of "cultural drug dependence" or "drug-facilitated sociability dependence" (Kennedy, 1987: p. 210; Odenwald, 2007: p. 12). As Shelagh Weir (1985: p. 53) long ago pointed out, the popularity of khat and chewers' willingness to spend good sums of cash on it rests on the social and cultural aspects rather than on explanations of physical addiction.

Social scientists who are familiar with khat and interested in drug policy formulation are of the view that the law enforcement approach to combat khat was formulated based on a distorted understanding of the chew culture. In the opinion of Bob Burrows, a professor of Middle East politics at the University of Washington, "No one except the US government asserts khat is particularly addictive... Another thing is there is no hallucinating. Khat gives a sense of well being. It's a very social thing” (Huus, 2007; Stancliff, 2009). This means, khat cannot deliver the quick and intense experience that the popular street drugs do in the West. People are "hooked" to the socializing that accompanies the hours of chewing together rather than the direct effect of the substance (Weir, 1985: p. 53; Carrier, 2007b: p. 199; Varisco, 1986: pp. 4-6). That is why, Eric Sterling, pre-

\footnotetext{
${ }^{4}$ Alem \& Shibre (1997) have reported a case where a patient killed his wives and his daughter with khat in his system. Alem et al. (1999) also described a case of combined homicide and suicide after chewing large amounts of khat. There is nevertheless no evidence to suggest a causal association between the deaths and khat use.
}

sident of the nonprofit Criminal Justice Policy Foundation, contests the notion that khat could become a "gateway drug" to more potent ones or that it could be transformed to yet another dangerous drug in American streets. He states: "My understanding of the use of khat is that it should be a very low priority for federal law enforcement. I think the cases are largely a waste of very precious federal criminal justice resources" (quotes from Huus, 2007; Stancliff, 2009).

So why is the government wasting scarce resource on controlling khat? Scott Lukas says it is a lack of understanding of why people chew khat. He states bluntly that

Khat is non-addictive. The problem with authorities is that because people who use khat need such a large amount for themselves, police misinterpret the amount of the substance seized and think it must be for street sale. That is not usually the intent. Large amounts of the leaves have to be chewed fresh or it loses its potency. A pound of chewed khat produces heightened awareness rather than euphoria (Mitchell, 2009).

For observers of US drug policymaking, the khat case is not a peculiar one. The US has been passing laws for many decades banning plants it suspects of potentially becoming an object of abuse. The reasons are not as benign as Lukas makes them when he attributes the reaction of US authorities to simple ignorance or cultural distance. For instance, the temperance movement and the Prohibition Amendment were in part the result of public hysteria over the impact of new immigrants from eastern and southern Europe on the existing culture. In addition, khat has been swept up in the "war on drugs" for fear that it might become a new dangerous drug. Because khat accompanied new immigrants from those areas of the world that most Americans view with deep suspicion or at least are less familiar with, a legal vegetable in other Western countries has been made a major threat to society that must be "nipped at the bud" (Cullen, 2007). This reaction is consistent with the time-honored American anti-immigration hysteria that pops up during difficult times (Musto, 1999: pp. 294-295; Helmer, 1976).

In the wake of the events of September 11, 2001, khat's connection to the Horn of Africa has touched off another panic button of the law enforcement establishment in the US. Authorities increasingly began to tie khat to terrorism. In a testimony before the Senate Judiciary Committee on May 20, 2003, Steven C. McCraw, FBI Assistant Director of the Office of Intelligence remarked:

The Al-Ittihad al-Islami, or AIAI, Somalia's largest militant Islamic organization, is suspected of smuggling an illegal narcotic leaf known as Khat ("cot") into the United States. Arrests and shipment seizures indicate a sharp increase in demand for the drug. Proceeds from East African Khat sales are likely remitted to Middle Eastern banks via Hawala network and wire services. It is likely that these funds pass through the hands of suspected AIAI members and other persons with possible ties to terrorist groups (McCraw, 2003).

In 2005, Harvey Kushner, director of the criminal justice department at Long Island University, published a book, Holy War on the Home Front. He devoted a chapter of his new book to explaining an alleged connection between khat and terrorism. He charged that "every law enforcement and drug agency in the country has missed the Arab-East African drug-smuggling network operating in America (Kushner, 2004: p. 75). His primary hypothesis was that there were significant linkages between an illegal khat trade and terrorism but the federal government has failed to launch a national investigation. Kushner called for 
congressional investigation into the failure of the homeland security bureaucracy to give top priority to an estimated $\$ 1.5$ billion khat smuggling industry into the US, which produces an illegal cash flow back to Great Britain, Somalia, Kenya and Yemen (Kushner, 2004: pp. 78-80). In an interview with a CBS affiliate in New York City, Kushner made his charge explicit: "You don't have to make a quantum leap to link drug smuggling from the Middle East, to Middle Eastern communities and ...the great possibility of that funding terrorist conspiracies, both here and abroad" (quoted in Carrier, 2007b: p. 198). It is of course highly unlikely that a substance that is a legal vegetable in the UK will be a lucrative business in the US capable of funding expensive terrorist projects. Kushner nevertheless asserted that "Khat and the Holy War on our home front are more dots federal authorities have failed to connect since 9/11 (Kushner, 2004: p. 94). His book chapter was an attempt to connect the War on Drugs, the War on Terror, and the opposition to illegal-immigration, using khat as the case of convergence for all three concerns.

Unbeknownst to Kushner however, federal officials were actually on the case. On July 26, 2006, the Organized Crime Drug Enforcement Task Force announced that it had completed "Operation Somalia Express," an 18-month investigation of khat trafficking. It resulted in the indictment of alleged members of an international Somali trafficking organization and the seizure of five tons of khat valued at $\$ 10$ million. Echoing Harvey Kushner's suggested lines of inquiry in their investigation, Mark Mershon, FBI assistant director in charge of the operation declared that the profits from the sale of khat were headed for "countries which are a hotbed for Sunni extremism and a wellspring for terrorists associated with Al-Qaida” (NY1 News Report, 2006). It all seemed a self-congratulatory exercise, given that the dollar value was off the mark for the amount of khat seized and also that for Al-Qaeda members transporting and selling khat is a violation of the Qur'an (Armstrong, 2008: p. 640). What compels smugglers to engage in high risk activity must be a low volume, high value commodity, the reward of which justifies the risk. Khat is bulky. The volatile nature of its active ingredient increases uncertainty of a handsome return. The potential reward is not worth the risk. From the vantage point of US officials, khat had been used by America's enemies, such as extremist Somali fighters, and it was not a stretch for them to make the fight against khat a part of the "war on terrorism.” Oddly for federal law enforcement authorities, though, just months after their much vaunted operation in New York, Somalia's Islamic Courts Union banned khat in Mogadishu, putting federal prosecutors who took up the case on the same side with the al-Qaida franchise in Somalia (Weinberg, 2006).

Could it be that law enforcement officials in the US were intent on preventing khat from spreading to American streets? For John Gilbride, head of the New York DEA and a member of the task force, stopping khat-related crime or preventing khat from spilling over to the local population did not factor into the rationale for the massive government operation. He says: "There's no real related spin-off crime (burglaries, robberies, shootings); it's traded and consumed in private, not out on the street... there's no proof it has spread beyond the small Somali and Yemeni communities scattered throughout the United States" (Gardiner, 2006). So what was the purpose of the massive operation? Gilbride's response is revealing of the mindset of authorities.

Unlike other drug dealers, none of the khat traffickers who have been caught had anything to show for it. No boats, no Escalades, no second homes, no offshore bank accounts, no bling whatsoever. We know the money from khat sales is not staying in the US, it's leaving. Our task now is to find out where the money is going (Gardiner, 2006).

Gilbride is aware of khat's significance in the traditional use areas. But he says "its's not his job to sort out the cultural and historical issues around khat. He’s just supposed to stop it from getting into the country” (Ibid). It is typical law enforcement attitude that the government cannot take the risk of deferring to culture when the issue at hand is "drug runners from an openly hostile Muslim country taking in millions, with nothing, ostensibly, to show for it" (Ibid). Khat became a part of the "war on terror."

Any consideration that khat might be a local custom for the new immigrants was jettisoned. In 2007, DEA official remarked:

"It is not coffee. It is definitely not like coffee. It is the same drug used by young kids who go out and shoot people in Africa, Iraq and Afghanistan. It is something that gives you a heightened sense of invincibility, and when you look at those effects, you could take out the word 'khat' and put in 'heroin' or 'cocaine"” (Dizikes, 2009).

In the opinion of Judge John D. Holschuh of the Sixth Circuit Court of Appeals, "there is absolutely no evidence that the khat plant with its cathinone and cathine ingredients presented a significant problem to the population of the United States" (quoted in Armstrong, 2008: p. 641) Many experts maintain that there is no evidence that its appeal extends beyond the immigrant communities. Peter Reuter, a professor at the University of Maryland's department of criminology, states that khat "is a very culturally specific drug. It's so hard to think that there's a great public issue here. It's not that khat has become the new yuppie drug... It's got no cachet” (quoted in Huus, 2007). His informed opinion is no consolation for the Oromo and other immigrants who came from the countries where khat was used for centuries and now finding themselves up against the hard line position taken by the authorities of their new country. But drug laws have always been used in the United States to control new immigrants (cf. (Musto, 1999: pp. 294-295; Helmer, 1976).

\section{In an Ambiguous Setting}

The federal laws that apply to khat are ambiguous. In the absence of a clear case of controlling legal authority, states have enacted various laws. Just as a legal vegetable in the UK becomes a Schedule I controlled substance somewhere midway across the Atlantic, people have to navigate through a patchwork quilt of laws traveling across the US. Oromo immigrants found themselves caught up in the complexities of US laws. In 2009, when several local residents in South Sioux City, Nebraska, were arrested for possession of khat the news came as a surprise to the community (Sioux City Journal, 2008).

Accordingly, in October 2009, Midhaqsa D. Gada, an Oromo resident of South Sioux City, was pulled over for traffic violations by a South Sioux City police officer. In the search that ensued, police allegedly found khat in his vehicle and he was charged with felony drug possession. Under Nebraska law, possessing khat is a class IV felony punishable by up to five years in prison and a $\$ 10,000$ fine. Faced with this prospect, Midhaqsa entered into a plea agreement. He was subsequently 
sentenced in Dakota County District Court. Under the terms of the agreement, prosecutors agreed to ask the court to sentence Midhaqsa to 24 months of probation, a \$1000 fine, \$500 restitution to the county. They also recommended that he be sentenced to perform 100 hours of community service and obtain a substance-abuse evaluation (Montag, 2010).

Earlier in February of the same year, Harun Geno, another Oromo from South Sioux City, and his friends were charged with three other people for illegal drug possession after a Nebraska State Trooper reportedly discovered khat in their vehicles during a series of traffic stops in South Sioux City. Court documents show that the trooper found packaged khat hidden under the front seat of all of the vehicles of the defendants. In fact, court documents state that Harun was chewing khat when he was pulled over and when asked what he was chewing on, he told the trooper it was "cooked cabbage" (Montag, 2010).

An interesting dimension to the South Sioux City situation is that khat was brought to the attention of the authorities by members of the community. Landlords reportedly started finding dried-out khat left behind when some Oromo and other tenants from the Horn of Africa moved out of their homes and apartments and reported their "discovery" to police. By 2009, the Horn of Africa community had been growing in the greater Sioux City area for some time. Their presence was made apparent by a number of African restaurants, grocery stores and related businesses. One cannot tell whether it was the khat or an aversion to the lifestyle of the immigrants that motivated the landlords to report their finding to the police (Ibid).

According to Sgt Chernock of the South Sioux City police, his questions about khat "were met with a surprise by the immigrant community.” At first, says Chernock, "[the immigrants] didn't seem to think it was anything to be upset about. They couldn't understand why we were interested in it." Officer Matt Hattermann, a drug recognition expert of the police department, suggests that the immigrants "got away with khat possession at first by telling police it was tea. Now that officers know what it is, and word has gotten out that khat is illegal here" (Ibid). From the immigrants' perspective, describing khat as tea may not have been meant to be evasive, as Hattermann claims. Referring to tea presents a comparison with the closest familiar thing the Americans could understand. Users found no need to be evasive about a substance that had always been legal and part of their culture.

In an interview with the local media, Edris Genemo, president of the Siouxland Oromo Community Association, spoke for many of his compatriots when he said:

Growing and using khat isn't merely legal in many East African countries, it's also one of the region's cash crops. It's grown in every garden. Many East African immigrants are surprised to learn khat is illegal here because it is treated as food or drink, not an illicit drug, in the part of the world they come from. It's chewed on a daily basis and considered on par with food or drink. People use it to pass the time or something nice to offer visitors or guests. Everybody, they use (khat). It's not illegal (Ibid).

Before coming to the United States several years ago, Edris worked for Ethiopia's Ministry of Agriculture. He told a local newspaper reporter that:

"Khat [is] one of the country's chief exports. There is even a union for workers who tend the plants in the thousands of acres of khat grown commercially in farm fields. The Ethiopian government actually profits by taxing the sale and export of khat, which growers can't send overseas without getting government permits or licenses" (Ibid).

In his new country of residence, however, possession of khat is a serious violation of the law. Edris's organization endeavors to warn new arrivals not to use khat in Siouxland, because they could be arrested and sent to jail.

Many Oromos have been arrested and their cases brought to trial across the US. In January 2006, Abdi Abdurahman Yousuf and Mulata Y. Ali, both of South Sioux City were charged for possession of khat. They were arrested with Jemal Mohamed Farah of Minneapolis after Ibsa Abdullahi, a roommate of Abid and Mulata, made a complaint with the police department that khat could be found in the apartment (Ebaugh, 2006;). In the first case to go on trial, the defendant was acquitted. Sarah Walters, the jury forewoman, explained the reason for the jury's not guilty verdict as follows. "The judge's instructions were very clear and this didn't meet the criteria to convict. It said he had to knowingly possess seven grams of cathinone, and clearly there wasn't that much there. It's not even clear if he knew there was any left [in the leaves]" (Ebaugh, 2006).

In August 2008, Tola Hassan of Richfield and Mohamed Ibro of Brooklyn Center, both of Minnesota, were charged in Sioux Falls, South Dakota, "in connection with the seizure of a large quantity of an African drug that produces a high similar to methamphetamine. They were arrested after an investigation involving local, state and federal authorities" (Sioux City Journal, 2008). At trial, Tola Hassan was "found guilty of possessing and intending to distribute khat, a drug that contains a stimulant similar to meth” (Dunsmor, 2009).

The difference in outcome of the two cases results from how each case is defined by prosecutors and the clarity of instruction given by the judge. Whenever the case was about the defendant having knowledge of the khat plant containing cathinone, the scheduled substance according to US laws, the prosecution invariably found it difficult to convince the jury of the defendant's intent. In such cases, the court proceedings ended with acquittals or dismissals. If the trial was about possessing khat itself with the intent to distribute, in most cases, the defendant's attorneys failed to mount a successful defense.

All this emanates from ambiguous state of knowledge about khat and the confusing language used by federal agencies in connection with khat. To comply with UN Convention on Psychotropic Drugs of 1971, on May 17, 1988, the US Department of Health and Human Services added cathine to the federal register of controlled substances (Federal Register vol. 53, reg. at 17459). On January 14, 1993, the DEA added cathinone to the federal register of controlled substances (Federal Register vol. 58, reg. at 4316). The rule did not explain the nature of the link with khat, but the Supplementary Information appended to the rule does describe the connection between khat and cathinone as: "When khat contains cathinone, khat is a Schedule I substance. When khat does not contain cathinone, but does contain cathine, khat is a Schedule IV substance” (Federal Register vol. 58, reg. at 4317). The rules themselves were later published in the Code of Federal Regulations (CFR), but the supplementary information was never formally incorporated into the rules, and, thus, no reference to khat appears in the CFR. The DEA chose both times not to list the plant itself as scheduled substance and thus the plant remains in a legal grey area, even though the DEA considers khat an "illegal plant.” By conflating khat with its alkaloids, US authorities have transformed a substance the Oromo immigrant communities viewed 
as more akin to espresso coffee into a dangerous drug on par with cocaine, LSD, or ecstasy (Renteln, 2009: p. 75).

Media representations have done their share to add to the confusion surrounding khat's effects. There is clear progression of khat from being viewed as a desirable activity to a benign habit to a deadly drug in its representation and in popular perception. In one of the earliest reports on khat, Lucy Howard and Gregory Cerio (1992: p. 4), likened khat's effects to caffeine's. A few years later, Stephanie Siek (2002) reported that khat has the same effect as drinking "two or three beers." Later in the year, the Associated Press reported that khat is "considered slightly less potent than marijuana.” By 2006, perceptions had begun to change. Tom Downey of the New York Times traveled to Yemen to learn about khat first-hand. He concluded that khat “induces mild euphoria” (Downey, Dec. 10, 2006). Sherry Williams (2006), a reporter for the Columbus Dispatch observed that east Africans considered chewing khat to be "much like drinking a couple of cups of coffee.” The following year a reporter of the Canadian Broadcasting Corporation noted that khat reportedly produced "a very mild cocaine or amphetamine high,” quoting the Royal Canadian Mounted Police (CBC, Jan. 26, 2007; RCMP, 2005, 22). According to an Associate Press (January 11, 2007) report, khat "produces cocaine-and morphine-like effects."

The scientific literature does not clarify the confusion. The list of ailments attributed to khat chewing gives one the impression that no part of the human body, from the hair to the toes, escapes the dangerous effects of the evil leaves of the cursed tree. It is claimed that khat affects the nervous, digestive, respiratory, reproductive, cardiovascular systems, and other functions of the human body (Cox \& Ramps, 2003: p. 460). But the scientific evidence is tentative with regard to khat's pharmacological effects and certainly more nuanced than the proponents of prohibition make it out to be. With regard to khat's effect on the human reproductive system, for instance, some studies suggest that it affects all semen parameters and produces abnormalities in sperm morphology (Islam et al., 1990; El-Shoura et al., 1995). Others show that khat actually stimulates sperm production, and had no deleterious effect on the testis (Al-Mamary et al., 2002). More recently, it was shown that some of the active chemicals in khat strengthened the sperm, suggesting that they may enhance natural fertility (Adeoya-Osiguwa \& Fraser, 2005). In addition there is some, albeit inconclusive, evidence of khat as an aphrodisiac (Al Motarreb et al., 2002).

When it comes to the effect of khat chewing on oral health, the literature is not just inconclusive but also contradictory. Based on the length of time that khat quid remains in the mouth and the usually discolored teeth of chewers, many suggest that khat-chewing must be detrimental to oral health. But studies conducted in Yemen and Kenya show the prevalence of dental and periodontal diseases was generally lower among khatchewers than non-chewers. Interestingly, the studies showed significantly lower periodontal and dental diseases in the chewing sides of the mouth of chewers, suggesting that khat had a beneficial effect on the chewing side or an adverse effect on the nonchewing side (Hill \& Gibson, 1987; Jorgensen \& Kaimenyi, 1990; Al-Hebshi \& Skaug, 2005). The studies conclude that the oral hygiene status of khat chewers was generally better than

${ }^{5}$ The references were assembled and shown in a table by Armstrong (2008: p. $635)$. I track them down to the sources for context and meaning. that of non-chewers and there was no evidence to show that chewing is detrimental to periodontal health.

Similar inconsistencies exist in the studies on the effect of khat chewing on mental health. Some studies maintain that khat causes psychological disturbances (Alem \& Shibre, 1997). Others acknowledge that khat chewers suffer mental disorders but see no direct association between chewing and any form of psychosis (Kalix \& Braenden, 1985). This means the cause of the disorders could be attributed to a host of other factors besides khat chewing. Many scholars working in this area concede that it is extremely difficult, if not impossible, to establish a cause and effect relationship between khat and mental disorder based on surveys and observations which suggest multifactorial genesis of psychosis (Warfa, Bhui, \& Craig, 2006; Warfa et al., 2007; Odenwald, 2007).

Looking through a glass darkly, law enforcement has decided to come down on the more definitive side of including khat in the more familiar terrain of drugs of abuse rather than leaving ambiguity. The dominant view in the US today is that khat possession is a criminal act. Some of those caught in this snare of a confused system were able to mount their legal defense claiming that a layman would not know that the chemicals listed in the schedules were constituents of the khat in his/her possession or whether he or she knows the amount of the controlled substance in the leaf (Renteln, 2004: p. 75). As noted, the Second, Fourth and Sixth Circuit Courts have sided with the appellants citing that the khat plant is not specified as a controlled substance by any law. These rulings did not stop the DEA from detaining unsuspecting immigrants coming into the US. In some cases, passengers caught with khat, including British citizens of non-Horn of Africa origins, have been deported under a plea agreement with prosecutors (Daugherty, 2010). Many settled immigrants are serving their sentences in prison with no hope of reuniting with their families when they had served out their time.

\section{Conclusion}

Despite the legal difficulties, khat plays an important role for some Oromo immigrants in the West. The chewing sessions, associated with sociable, loquacious, and recreational experiences, provide a setting that transports them back to their country of origin. It connects them with people who are familiar with their way of life and as such eases the trauma of dislocation and integration into the new cultural milieu. It requires a serious study to determine whether khat chewing among the Oromo is declining, holding steady, or rising. But one can speculate that, because of the benefits of socializing the chew sessions offer, khat is likely to continue to be used by many people in the Oromo diaspora communities.

Just as chewing coca leaves is different from taking pure cocaine, chewing khat has a more gentle effect than would be the case taking isolated cathinone. US laws make a distinction with regard to coca leaves and cocaine but the same standard does not apply to khat. Powerful cultural and political forces have coalesced to create a political environment in which legislation and policies are formulated based on emotion rather than empirical facts. The political environment is therefore not conducive for a more rational and uniform national law to be instituted as long as the US policy gives a priority to the "war on drugs" and the "war on terror" and immigration concerns remain high on the minds of voters and elected officials. Operat- 
ing in a politically-charged environment, it is unlikely that law enforcement officials will adopt an individualized approach to dealing with various cases. The new immigrants are challenged to find other venues than the khat chew sessions to connect to their home while doing more to integrate into their new settings.

\section{REFERENCES}

Adeoya-Osiguwa, S. A., \& Frazer, L. (2004). Cathine and norephedrine, both phenylpropanolamines, accelerate capacitation and then inhibit spontaneous acrosome loss. Human Reproduction, 20, 198-207. doi:10.1093/humrep/deh566

Advisory Council on the Misuse of Drugs (ACMD). (2005). Khat (Qat): Assessment of risk to the individual and communities in the UK. London: Home Office.

Ahmed, H. (2010). Tradition and innovation in the ritual of khat consumption in Wallo, Northern Ethiopia. In E. Gebissa (Ed.), In taking the place of food: Khat in Ethiopia (pp. 13-28). Lawrenceville, NJ: The Red Sea Press.

Alem, A., \& Shibre, T. (1997). Khat induced psychosis and its medicolegal implication: A case report. Ethiopian Medical Journal, 35, 137141.

Al-Hebshi, N. N., \& N. Skaug. (2005). Effect of khat chewing on 14 selected periodontal bacteria in sub- and sup-ragingival plaque of a young male population. Oral Microbiology and Immunology, 20, 141-146. doi:10.1111/j.1399-302X.2004.00195.x

Al-Mamary, M., Al-Habori, A. M., Al-Aghbari, M., \& Baker. M. (2002). Investigation into the toxicological effects of Catha edulis leaves: A short term study in animals. Phytotherapy Research, 16, 127-132. doi:10.1002/ptr.835

Al-Motarreb, A. K. B., \& K. Briadley. (2002). Khat: Pharmacological and medical aspects and its social use in Yemen. Pyschotherapy Research, 16, 403-413.

Anderson, D., \& Carrier, N. (2006). Flowers of paradise, or polluting the nation: Contested narrative of Khat consumption. In Conusming cultures, global perspectives: Historical trajectories, transnational exchanges (pp. 145-166). Oxford \& New York: Berg.

Argawv Ashcroft. (2005). Argawv Ashcroft No. 03-2436 (United States Court of Appeals for the Fourth Circut, 31 January 2005).

Armstrong, E. G. (2008). Crime, chemicals, and culture: On the complexity of Khat. Journal of Drug Issues, 38, 631-648. doi:10.1177/002204260803800212

Associated Press. (2007). Woman indicted on drug charges. Baltimore, AP: Assoiciated Press.

Beckerleg, S. (2008). Use, users and unresolved issues-Khat special edition introduction. Substance Use and Misuse, 42, 749-760. doi:10.1080/10826080701739057

Bentur, Y., Bloom-Krasik, A., \& Raikhlin-Eisenkraft, B. (2008). Illicit cathinone ("Hagigat”) poisoning. Clinical Toxicology, 46, 206-210. doi:10.1080/15563650701517574

Blount, J. (1996). Sort of legal. Sort of not. Somali wonder drug. Makes you hot. Saturday Night, March 1996. URL. http://connection.ebscohost.com/c/articles/9603115808/.

Bowdern, M. (1999). Black hawk down: A story of modern war. New York: Atlantic Monthly Press.

Bulcha, M. (2002). The making of the oromo diaspora: A Historical sociology of forced migration. Minneapolis: Kirk House Publishers.

Carrier, N. (2007b). A strange drug in a strange land. In A. Pieroni, \& I. Vanderbroek (Eds.), Traveling cultures and plants: The ethnology and ethnopharmacy of human migrations (pp. 186-203). New York \& Oxford: Berghahn Books.

Carrier, N. (2007a). Kenyan khat: The social life of a stimulant. Leiden: Brill Academic Publisher. doi:10.1163/ej.9789004156593.i-288

Crenshaw, J. M., \& T. Burk. (2004). Khat: A potential concern for law enforcement. FBI Law Enforcement Bullentin, 10-13.

Cullen, S. (2007). Man gets jail time for dealing in khat. Wisconsin State Journal, 15 March 2007.

Drug Enforcement Aminstration (DEA). (2003). Intelligence bulletin: Khat (Catha edulus). Johnstown, PA: US Department of Justice.
Daugherty, S. (2010). Khat smugglers deported: 2 Brits brought 95 pounds to BMI. The Capital, Annapolis Maryland, 3 March 2010.

Dizikes, C. (2009). Khat-Is it more coffee or cocaine? The narcotic leaf is a time-honored tradition in Africa but illegal in the US, where demand is growing. Los Angles Times. 3 January 2009. URL (last checked 30 September 2009). http://articles.latimes.com/2009/jan/03/nation/na-khat3

Downey, T. (2006). Yemen: An arabian oasis for the intrepid. The New York Times, 10 December 2006. URL. http://travel.nytimes.com/2006/12/10/travel/10adventure.html

Drug Connection. (1989). Khat. Drug Connection.

Dunsmoor, B. (2009). Man Convicted of having African drug in tea. Feature Report, Sioux City: Keloland TV. URL. http://www.keloland.com/NewsDetail6162.cfm?Id=91123

Ebaugh, A. (2006). Trial opens for immigrants after khat seized. Sioux City Jounral, 25 January 2006. URL.

http://m.siouxcityjournal.com/news/article_ee26254a-c119-5d69-a20 6-9fe12fc84cb8.html

Ebaugh, A. (2006). Jury acquits immigrant in khat drug trade. Sioux City Journal, 26 January 2006. URL.

http://ethiomedia.com/courier/khat_trader_acquitted.html

Economist. (1992). Somalia: Death by Looting. The Economist, 18 July 1992.

El-Shoura, S. M., Abdel Aziz, M., Ali, M. E., El-Said, M. M., Ali, K. Z., \& Kemeir, M. A. (1995). Deleterious effects of khat addiction on semen parameters and sperm ultrastructure. HumanReproduction, 10, 2295-2300.

Gardiner, S. (2006). That darned Khat: In search of New York City’s most illusive drug. The Village Voice, 14 November 2006.

Gebissa, E. (2010). Keeping tradition and killing time: The use and misuse of khat in Ethiopia. In E. Gebissa (Ed.), Taking the place of food: Khat in Ethiopia (pp. 57-88). Lawrenceville NJ: The Red Sea Press.

Gebissa, E. (2010). Khat in the Horn of Africa: Historical perspectives and current trends. Journal of Ethnopharmacology, 132, 607-614. doi:10.1016/j.jep.2010.01.063

Gebissa, E. (2004). Leaf of Allah: Khat and agricultural transformation in Harerge, Ethiopia. Oxford: James Currey, 1875-1991.

Getahun, S. A. (2006). The history of Ethiopian immigrants and refugees in America, 1900-2000: Patterns of migration, settlement, survival and adjustment. New York: LFB Scholarly Publishing LLC.

Giradet, E. (1992). A forgotten face of war. US News \& World Repor, May 1992, 28-41.

Grayson, K. (2008). Chasing dragons: Security, identity, and illicit drugs in Canada. Toronto: University of Tronto Press.

Hart, J. (1997). Khat happenss. City Pages, 18 June 1997. URL. http://www.citypages.com/1997-06-18/news/khat-happens/

Hays, T. (2000). Khat comes to America, prompting crackdown. The Associated Press State \& Local Wire, 23 April 2000.

Helmer, J. (1975). Drgus and minority control. New York: Seabury Press.

Hennepin County. (1989). The drug connection. Occasional Publication.

Hill, C. M., \& A. Gibson. (1987). The oral and dental effects of qat chewing. Journal of Oral Pathology \& Medicine, 33, 368-372.

Howard, L., \& Cerio, G. (1992). Khat scum. Newsweek, 28 December 1992, 4.

Huus, K. (2007). Making a federal case out of an obscure leaf Courts to decide if khat is an illicit drug or more like a double espresso. 22 May 2007. URL (last checked 31 July 2011).

http://www.msnbc.msn.com/id/18096999/ns/us_news-crime_and_co urts/t/making-federal-case-out-obscure-leaf/

Islam, M. W., Tariq, M., Ageel, A. M., El-Feraly, F. S., Al-Meshal, I. A., \& Ashraf, I. (1990). An evaluation of the male reproductive toxicity of cathinone. Toxicology, 60, 223-234. doi:10.1016/0300-483X(90)90145-7

Jorgensen, E., \& Kaimenyi, J. T. (1990). The status of periodontal health and oral hygiene of Miraa (Catha edulis) chewers. East African Medical Journal, 67, 585-590.

Kalix, P., \& Braenden, O. (1985). Pharmacological aspects of the chewing of khat leaves. Pharmacological Review, 37, 149-164.

Kennedy, J. (1987). The flower of paradise: Institutionalised use of the 
drug khat in North Yemen. Dordrecht: D. Reidel Press.

Kumsa, M. K. (2005). Betweem home \& exile: Dynamics of negotiating belonging among young Oromos living in Toronto. In K. P. Pupalampu, \& W. Tettey (Eds.), The African diaspora in Canada: $\mathrm{Ne}$ gotiating identity and belonging (pp. 175-204). Calgary: University of Calgary Press.

Kushner, H., \& Bart D. (2004). Holy war on the home front: The secret Islamic terror network in the United States. New York: Sentinel.

Kwiatkowski, J. (1993). Police note increase of khat, a new drug on streets but old custom in some homes recent seizure suggests imports increasing. Buffalo News, 2 May 1993. URL.

http://www.highbeam.com/doc/1P2-22508019.html

Lancaster, J. (1997). Chewing the Khat: A LUMPY DUd. Washington Post, 12 May1997, B01.

Litman, A., I. Levav, \& H. \& Maoz, B. Saltz-Rennert. (1986). The use of khat. An epidemiological study in two Yemenite villages in Israel. Culture, Medicine and Psychiatry, 10, 389-396. doi:10.1007/BF00049272

Mains, D. (2010). Chewing and dreaming: Youth, imagination, and the consumption of khat in Jimma, Southwestern Ethiopia. In E. Gebissa (Ed.), Taking the place of food: Khat in Ethiopia (pp. 29-56). Lawrenceville, NJ: The Red Sea Press.

Manghi, R. A. et al. (2009). Khat use: Lifestyle or addiction? Journal of Psychoactive Drugs, 41, 1-10. doi:10.1080/02791072.2009.10400669

McCraw, S. (2003). Testimony before the united states senate committee on the judiciary. Washington DC: US Senate Committee on the Judiciary. URL. http://judiciary.senate.gov/

Mitchell, C. (2001). Brooklyn Yemenis indignant over police raids to seize leaves of the stimulant khat. Student Work, New York: The Journalism School, Columbia University.

http://web.jrn.columbia.edu/studentwork/humanrights/khat-mitchell.asp

Montag, M. (2010). Cultures collide in Siouxland over legality of khat plant. Sioux City Journal, 1 February 2010. URL.

http://m.siouxcityjournal.com/news/local/article_b6899dbc-a0a7-5f2 2-8edd-bb4a9130678a.html

Musto, D. F. (1999). The American disease: Origins of narcotic control (3rd ed.). New York: Oxford University Press.

Nasir W., Klein, A., Bhui, K., Leavey, G., Craig, T., \& Stansfeld, S. A. (2006). Khat use and mental illness: A critical review. Social Science \& Medicine, 65, 309-318.

NY1. (2006). Feds bust major African drug ring with NYC ties. 26 July 2006. URL (last checked 1 August 2011).

http://www.ny1.com/content/top_stories/61315/feds-bust-major-afric an-drug-ring-with-nyc-ties

Odenwald, M. (2007). Chronic khat use and psychotic disorders: A review of the literature and future prospects. Sucht, 53, 9-22. doi:10.1024/2007.01.03

Renteln, A. D. (2004). The cultural defense. Oxford: Oxford University Press.

Siek, S. V. (2002). Use of drug up in US cities. New York: Associated Press.

Sioux City. (2008). African drug seized in Sioux Falls, two charged. URL (last checked 14 August 2008).

http://m.siouxcityjournal.com/news/article_1311b7cf-0997-5e79-bf4 f-2d8de9c459dd.html

Stancliff, D. (2009). Got khat? Paranoia leads to latest state ban on a plant. Eureka Standard-Times, 25 January 2009. URL. http://www.times-standard.com/othervoices/ci_11550184

Stevenson, J. (1992). Krazy khat: Somalia’s deadly drug war. The New Republic, 23 November 1992, 1-19.

Stevenson, M., Fitzgerald, J., \& Banwell, C. (1996). Chewing as a social act: Cultural displacement and khat consumption in the East African communities of Melbourne. Drug and Alcohol Review, 15, 7382. doi:10.1080/09595239600185691

Tafla, B. (1982). Addictives in North East Africa: A brief survey of an aspect of nineteenth century cultural history. Afrika und Ubersee, 64, 282-309.

Ukers, W. H. (1922). All about coffee. New York: The Tea and Coffee Trade Co.

United States Govenment. (1988). Federal register (Vol. 53). Washington DC, 17 May 1988.

United States Government. (1993). Federal Register (Vol. 58). Washington DC, 14 January 1993.

US Second Court of Appeals. (2008). United States v. Hassan. 05-6949-cr. (United States Court of Appeals for the Second Circut, 19 September 2008).

US Sixth Court of Appeals. (2005). United States v. Caseer No. 022268 (United States Court of Appeals for the Sixth Circut, 28 February 2005).

US News \& World Report. (1992). Strangers in strange land-US news \& world report. 21 December 1992, 60-61.

Urquhart, C. (2004). Drugs and dance as Israelis blot out intifada: Nightlife in Tel Aviv on a par with the best in London and New York. The Guardian, 4 September 2004. URL. http://www.guardian.co.uk/world/2004/sep/04/israel

Varisco, D. M. (1986). On the meaning of chewing: The significance of Qât (Catha edulis) in the Yemen Arab Republic. International Journal of Middle East Studies, 18, 1-13. doi:10.1017/S002074380003018X

Wallace, B. (1992). The cry of a dying people. Maclean's, 7 September 1992, 2-4.

Warfa N., Bhui K., \& Craig T. (2007). Post-migration geographical mobility, mental health and health service utilization among Somali refugees in the UK: A qualitative survey. Health Place, 12, 503-515. doi:10.1016/j.healthplace.2005.08.016

Weinberg, B. (2006). Next for Somalia: Khat wars? 22 November 2006. URL (last checked 0 August 2011).

http://www.ww4report.com/node/2817

Weir, S. (1985). Qat in Yemen: Consumption and social change. London: British Museum Press.

Williams, S. (2006). Somalis try to eradicate "bad habit" from Africa Tradition of chewing leaf has local community concerned; tougher law may emerge. The Columbus Dispatch, 27 November 2006. URL. http://www.dispatch.com/live/contentbe/dispatch/2006/11/27/200611 27-A1-01.html

World Health Organization. (2006). Assessment of khat (catha edulis frosk). Geneva: World Health Organization. URL.

http://www.who.int/medicines/areas/quality_safety/4.4KhatCritRevie sw.pdf 